\title{
Effect of timing of mineral oil spraying on budburst and metabolic changes in "Barkhar" apple trees under conditions of inadequate winter chilling in Egypt
}

\begin{abstract}
The impact of mineral oil at completely different dates to work out the foremost effective date for spraying buds of "Barkhar" apple (Malus sylvestris, Mill) trees was investigated. Also, their effects on metabolic changes within the content of buds from chemical substances throughout their release from dormancy were detected. The potency of early bud break was noticed in varied degrees with oil at completely different dates. It fully determined that the applied treatment at completely different dates results in early bud break, short flowering length, high percentages of bud break, fruit-set, yield/ tree $(\mathrm{kg}$ ), yield parts (number of fruits per tree, fruit weight, fruit size, fruit length and fruit width). Also as high contents of some chemical constituents of fruits (total soluble solids (TSS) and vitamin C) and low content of total acidity with the appliance of the various dates. Additionally, high contents of buds from water content, total carbohydrates, total sugars, total indoles, indole-3-acetic acid, gibberellin, total free amino acids, total flavonoids, total and conjugated phenols, as well as, low content of non- soluble carbohydrates, abscisic acid and free phenols were achieved. In line with the results, it's counseled that mineral oil spraying at 5\% in date of fifteen th of Jan as operator safer bud break promoters for reach to the first break dormancy in buds of "Barkhar" apple trees under Egyptian winter conditions and therefore the most yield by control the metabolic changes in buds.
\end{abstract}

Keywords: apple, dormancy, mineral oil, hormones, phenols, amino acids, carbohydrates, yield
Volume 3 Issue 2 - 2019

\author{
Mohamed A Seif El Yazal \\ Faculty of Agriculture, Fayoum University, Egypt
}

Correspondence: Mohamed A Seif El Yazal, Botany Department, Faculty of Agriculture, Fayoum University, 635।4-Fayoum, Egypt, Email mas04@fayoum.edu.eg

Received: November 21, 2018 | Published: April 17, 2019

\section{Introduction}

The term "dormancy" is related to temporary suspension of visible growth. It includes true dormancy ("rest" or "endodormancy") triggered by internal factors, and environmental condition dormancy ("quiescence" or "ecodormancy") controlled by external factors. Bud dormancy may be a crucial step within the phenology cycle, as its progression over winter determines the dates of bud break, flowering and fruit-set. ${ }^{1,2}$ These phases of dormancy are relieved by completely different elements: unleash of endodormancy needs cold accumulation here as ecodormancy advances with heat accumulation toward bud break. For perennial fruit species, within the context of worldwide warming, endodormancy unleash is also a crucial step within the future because of insufficient chill accumulation, directly touching flowering quality and uniformity, and therefore resulting in a forceful reduction of fruit production. In the past decades, several studies, supported metabolic, physiological, sub cellular, genetic, and genomic analyses, have unraveled mechanisms underlying bud dormancy progression. ${ }^{3}$ Mineral oil is that the most helpful rest breaking treatment for apple and has been used effectively to supplement cold temperature, to attain satisfactory bud break and to reinforce cropping. ${ }^{4-7}$ Moreover, the result of temporal arrangement of rest breaking agents on budburst were studied by many researchers. ${ }^{4,6,8,9}$ Initiation and break of dormancy are connected in different plant species to changes in endogenous growth regulations concentration. ${ }^{7,10-12}$ The relationship between plant phenols and bud dormancy likewise as bud break were studied by many researchers. ${ }^{7,12-15}$ Changes within the state of water are connected with bud dormancy in many woody plants. ${ }^{16}$ Water was certain at the start of dormancy and was free before growth was resumed. ${ }^{17}$ Numerous changes within the level of carbohydrates occurred in buds as they supported the non-growing stage and starting of growth. Starch accumulated throughout the amount of chemical action activity and was used for regeneration of growth within the spring. ${ }^{18}$ Changes in chemical compound like amino alkaloid acid profiles are related to the discharge of buds from dormancy. ${ }^{19}$ Because of the winter in Egypt is brief and doesn't meet the chilling necessities of buds, the delay in break the buds of "Barkhar" apple trees till late winter exposes them to break below the influence of hot temperature and/or delays them in getting into in dormancy within the following year ends up in some physiological defects which will lead to weakness and death. This threatens the "Barkhar" apple productivity in Egypt, therefore this work focuses in the main to elucidate the behavior of the plant growth regulations, phenols, sugars and total free amino acids contents in buds and their reflections within the length to full buds break, and also the percentages of bud break and fruit-set as a results of spraying "Barkhar" apple trees with oil at completely different dates elucidating their impacts in fast the dormancy break.

\section{Materials and methods}

\section{Trees selection and treatments}

Uniform, 14-year-old "Barkhar" apple trees (Malus sylvestris Mill) grafted on Malling-Merton 106 (MM 106) rootstock were chosenwilly-nilly, for a preliminary study in 2014/2015 and for the most analysis studies within the 2015/2016 and 2016/2017 seasons. All trees $(n=24)$ were grown in the Orchard of the Horticultural 
Station in Abshawai, Fayoum, Egypt (29170N; 30530E). For the most 2 -season study, chosen trees of every treatment $(n=6)$ were tagged in November 2015 and 2016, received the foliar treatments at completely different dates (1st Jan, fifteenth Jan and first Feb) of a similar two years and sampled from fifteenth December-15th February 2015/2016 and 2016/2017. Trees chosen for the study within the initial season isn't a similar tree that was chosen for the second season. Every tree was designed united replicate, and every treatment enclosed six trees (total $n=24$ ). Foliar-spray applications (4 1 tree-1; six trees per treatment) were conducted as follows: treatment 1 ; control trees did not receive any compound, only tap water; trees of treatment two were foliar sprayed in first of Jan to runoff with $5 \%(\mathrm{v} / \mathrm{v})$ mineral oil MO; Guangzhou Hanglian Chemical Industry Co. Ltd., Guangzhou, P. R. China); trees of treatment three were foliar sprayed in 15th of January to runoff with $5 \%(\mathrm{v} / \mathrm{v})$ mineral oil MO; trees of treatment 4 were foliar sprayed in 1 st February to runoff with $5 \%(\mathrm{v} / \mathrm{v})$ mineral oil (MO; All spray treatments were applied using 20 LKnapsack Sprayer. Triton B $[0.1 \%(\mathrm{v} / \mathrm{v})]$ was added as a wetting agent to each spray solution. A preliminary study was conducted in 2014/2015 during which MO were applied once at completely different dates for each. The rate of $5 \%(\mathrm{v} / \mathrm{v})$ was found to be the foremost vital concentrations for later bud growth in "Barkhar" apple trees (data not shown). These treatment levels were used later for the main study.

\section{Morphological characteristics and yield measurements}

Buds count was created for every tree of all treatments. The dates of floral buds began to open were recorded. Number of floral buds was counted for all buds once it had been opened and therefore the percentages were calculable. The dormant buds were additionally counted and expressed as a proportion of the overall range of buds. The dates at that flowering reached twenty fifth, fifty, seventy fifth and 100 percent of the overall flowers were calculable in every treatment. Flowers whose calyx began to extend were tagged Flowers in order to measure the percentage of fruit-set. At harvest stage, apple fruits were harvested, counted and weighed for every examined tree.

In order to determine fruit quality, ten fruits were taken arbitrarily from every tree as a sample. Samples were transferred straight off to the laboratory wherever physical analyses were undertaken. Fruit weight, size, diameter and height were measured. Every fruit within the sample was weighted to induce the common fruit weight. Average fruit size decided by rising the fruit in an exceedingly jar containing water and receiving the surplus water in an exceedingly graduate. The caliper was used for measure fruit diameter and height.

\section{Determination of endogenous hormone in apple buds}

In different experiments $(2 \mathrm{~g})$ floral buds were collected 15 day intervals beginning from 15 December up to 15 February for determining the metabolic changes in the hormonal content in buds. Buds were randomly sampled and immediately transported to the laboratory. Floral bud samples were taken from each tree of each treatment, frozen in liquid nitrogen and stored at $-20^{\circ} \mathrm{C}$ until extraction and assay as adopted and described. ${ }^{20,21}$

\section{Determination of total indoles in apple buds}

Total indols in buds were determined as $\mu \mathrm{g} / \mathrm{g}$ fresh weight according. ${ }^{22}$ Estimation of free, conjugated and total phenolics content in apple buds using folin-ciocalteu reagent. Total and free phenols in buds were determined as $\mathrm{mg} / \mathrm{g}$ fresh weight using folin-ciocalteu reagent and Sodium carbonate solution according. ${ }^{23}$

\section{Extraction and determination of total flavonoids in apple buds}

One hundred milligrams of samples was extracted with $10 \mathrm{ml}$ $80 \%$ aqueous methanol. The mixture was centrifuged for $10 \mathrm{~min}$ at $2,000 \mathrm{~g}$. The supernatants were used for subsequent analysis. The flavonoid content was measured employing the colorimetric assay described. ${ }^{24} 0.5 \mathrm{ml}$ aliquots of extracts were added to $10 \mathrm{ml}$ volumetric flask containing $4.5 \mathrm{ml}$ distilled water, $0.3 \mathrm{ml} 5 \%$ sodium nitrite was added to each aliquot after $5 \mathrm{~min}$, and then $0.6 \mathrm{ml}$ of $10 \%$ aluminum chloride was added. After $6 \mathrm{~min}, 2 \mathrm{ml}$ of $1 \mathrm{M}$ sodium hydroxide was added to the mixture, followed by the addition of $2.1 \mathrm{ml}$ of distilled water. Absorbance was recorded at $510 \mathrm{~nm}$, and flavonoid content was expressed as $\mathrm{mg}$ of rutin equivalent per gram of fresh weight.

\section{Total carbohydrate determination in apple buds}

\section{Procedure:}

Total carbohydrate was extracted from apple buds by placed $10 \mathrm{mg}$ dry sample with $10 \mathrm{ml}$ of $\mathrm{H}_{2} \mathrm{SO}_{4}(0.1 \mathrm{~N})$ in test tube and extracted on a boiling water bath for 30 minutes. The sample was filtered to remove the insoluble material. After filtering, the solution was completed to $100 \mathrm{ml}$ by distilled water. Carbohydrate contents were determined by phenol-sulfuric acid method. ${ }^{25}$ Briefly, to $1 \mathrm{ml}$ of sugar solution, $50 \mu \mathrm{l}$ $80 \%$ phenol and then $3 \mathrm{ml} 98 \%$ sulfuric acid was added. The mixture vortexed were kept at room temperature for $30 \mathrm{~min}$ and the absorbance read at $490 \mathrm{~nm}$

\section{Total sugars determination}

Total sugars were determined as $\mathrm{mg} / \mathrm{g}$ fresh weight using phosphomolybdic acid reagent. ${ }^{26}$

\section{Non soluble carbohydrates}

Non soluble carbohydrates were determined by subtracted total sugars from total carbohydrates.

\section{Total free amino acids determination in apple buds}

Total free amino acids were determined by reaction with ninhydrin using glycine as standard..$^{27,28}$

\section{Water content determination}

The water content of floral buds was determined by the methods specified. ${ }^{26}$

\section{Chemical determinations in fruits}

\section{Total soluble solids (TSS):}

The percentage of TSS in fruit juice was determined by a hand refractometer (CARL ZEISS JENA DDR 78 227 0...30\%).

\section{Total acidity:}

It was estimated in fruits as malic acid by using sodium hydroxide for a known normality and phenolphthalein as an indicator, according. 26

\section{Total soluble soluble solids /acid ratio}

The TSS/Acid ratio was calculated.

\section{Vitamin $C$ content:}

The Vitamin C content in fruits was determined according to the method described ${ }^{26}$ 


\section{Statistical analysis}

The values of the determined characters were subjected to statistical analysis according to the standard procedure described by. ${ }^{29}$ The ' $F$ ' test was applied to assess the significance of the treatment at $5 \%$ level of probability.

\section{Results}

\section{Date of floral bud break}

The foliar application of "Barkhar" apple trees with mineral oil at $5 \%$ on first, 15 th of January and first of February was hastened the floral bud break as comparison with the untreated trees during which trees were sprayed with water (Table 1). The period to the first floral bud break was shortened by four, five and three days, and six, seven and five days, respectively in the first and second season as comparison with the untreated trees. Additionally, the amount to full flowering were shortened by two, three and a pair of days and one, two and one days within the initial and second seasons, severally as compared to the untreated trees. The best results were obtained when mineral oil at $5 \%$ was sprayed on 15 th of January.

Table I Effect of mineral oil spray at different dates on the date of flower bud opening and flowering period in "Barkhar" apple trees

\begin{tabular}{|c|c|c|c|c|c|c|c|c|c|c|c|c|}
\hline \multirow{3}{*}{$\begin{array}{l}\text { Date of } \\
\text { spraying }\end{array}$} & \multicolumn{12}{|c|}{ Date of flower bud opening } \\
\hline & \multicolumn{2}{|c|}{ Beginning } & \multicolumn{2}{|c|}{$25 \%$ flowering } & \multicolumn{2}{|c|}{$50 \%$ flowering } & \multicolumn{2}{|c|}{ 75\% flowering } & \multicolumn{2}{|l|}{ End } & \multicolumn{2}{|c|}{$\begin{array}{l}\text { Flowering period } \\
\text { (day) }\end{array}$} \\
\hline & 2015 & 2016 & 2015 & 2016 & 2015 & 2016 & 2015 & 2016 & 2015 & 2016 & 2015 & 2016 \\
\hline \multirow[t]{2}{*}{ Control } & 10 & 11 & I3-Feb & I3-Feb & 15 & 16 & 17 & 18 & 24 & 26 & 15 & 16 \\
\hline & $\mathrm{Feb}$ & Feb & & & Feb & Feb & Feb & Feb & Feb & Feb & & \\
\hline \multirow[t]{2}{*}{ January, I } & 6 & 5 & 7 & 8 & 10 & 11 & 13 & 14 & 18 & 19 & 13 & 15 \\
\hline & Feb & Feb & Feb & Feb & Feb & Feb & Feb & Feb & Feb & Feb & & \\
\hline \multirow[t]{2}{*}{ January, 15} & 5 & 4 & 7 & 7 & 10 & 11 & 13 & 15 & 16 & 17 & 12 & 14 \\
\hline & Feb & Feb & Feb & Feb & Feb & Feb & Feb & Feb & Feb & Feb & & \\
\hline \multirow[t]{2}{*}{ February, I } & 7 & 6 & 10 & 9 & 13 & 14 & 16 & 17 & 19 & 20 & 13 & 15 \\
\hline & $\mathrm{Feb}$ & Feb & Feb & Feb & $\mathrm{Feb}$ & Feb & Feb & Feb & $\mathrm{Feb}$ & Feb & & \\
\hline
\end{tabular}

\section{Floral bud break and fruit set}

Table 2 shows that, all tested dates considerably increased the percentages of floral bud break and fruit-set in comparison to the control. However, mineral oil sprayed at $5 \%$ on fifteenth of January was the foremost effective than all others. It surpassed the faucet water by $5.72-11.10 \%$ and $35.25-46.60 \%$ for bud break and fruit-set within the first and second seasons, severally.

Table 2 Effect of mineral oil spray at different dates on the percentage of bud break and fruit set in "Barkhar" apple trees

\begin{tabular}{lllll} 
Date of spraying & \multicolumn{2}{c}{ Bud break (\%) } & \multicolumn{2}{c}{ Fruit-set (\%) } \\
& $\mathbf{2 0 I 5}$ & $\mathbf{2 0 1 6}$ & $\mathbf{2 0 1 5}$ & $\mathbf{2 0 1 6}$ \\
\hline Control & $77.53 \mathrm{~b}$ & $75.00 \mathrm{~b}$ & $58.55 \mathrm{c}$ & $54.1 \mathrm{lc}$ \\
January, I & $81.43 \mathrm{a}$ & $83.06 \mathrm{a}$ & $77.87 \mathrm{a}$ & $76.25 \mathrm{a}$ \\
January, I5 & $81.97 \mathrm{a}$ & $83.33 \mathrm{a}$ & $79.19 \mathrm{a}$ & $79.33 \mathrm{a}$ \\
February, I & $81.59 \mathrm{a}$ & $83.96 \mathrm{a}$ & $64.82 \mathrm{~b}$ & $69.14 \mathrm{~b}$ \\
\hline
\end{tabular}

Mean pairs followed by different letters are significantly different $(p=0.05)$ by Duncan's test; $n=6$

\section{Fruit yield and its components}

Table 3 shows that, all tested dates increased number of apple fruits tree- 1 and total fruit yield tree- 1 when compared to the untreated trees. Mineral oil sprayed at $5 \%$ on 15 th of January was most effective only during this concern. It exceeded the untreated trees by $36.16-$ $39.74 \%$ and $43.17-58.57 \%$ for number of fruits tree- 1 and fruit yield tree- 1 in the two experimental seasons, respectively. The maximum increases in yield components (fruit weight, fruit size, fruit length, fruit width and number of fruits/tree) were recorded with mineral oil sprayed at $5 \%$ on 15 th of January (Table 4) (Table 5).

Table 3 Effect of mineral oil spray at different dates on No. of fruit tree-I and total yield tree-I of "Barkhar" apple trees

\begin{tabular}{lllll}
\hline $\begin{array}{l}\text { Date of } \\
\text { spraying }\end{array}$ & \multicolumn{2}{l}{ No. of Fruit tree ${ }^{-1}$} & \multicolumn{2}{l}{ Total yield tree $\left.^{-1} \mathbf{( k g}\right)$} \\
& $\mathbf{2 0 1 5}$ & $\mathbf{2 0 1 6}$ & $\mathbf{2 0 1 5}$ & $\mathbf{2 0 1 6}$ \\
\hline Control & $474.17 \mathrm{c}$ & $465.1 \mathrm{Ic}$ & $24.04 \mathrm{c}$ & $21.58 \mathrm{c}$ \\
January, I & $643.34 \mathrm{~b}$ & $645.28 \mathrm{~b}$ & $33.79 \mathrm{~b}$ & $32.39 \mathrm{~b}$ \\
January, I5 & $645.63 \mathrm{~b}$ & $649.98 \mathrm{~b}$ & $34.42 \mathrm{~b}$ & $34.22 \mathrm{~b}$ \\
February, I & $635.84 \mathrm{a}$ & $636.2 \mathrm{la}$ & $33.39 \mathrm{a}$ & $33.47 \mathrm{a}$ \\
\hline
\end{tabular}

Mean pairs followed by different letters are significantly different $(p=0.05)$ by Duncan's test; $n=6$

\section{Water content in buds}

Table 6 indicates that water content in floral buds of "Barkhar" apple trees were increased when mineral oil at $5 \%$ was applied. The best results were recorded when mineral oil was sprayed on the 15th of January as compared to the control during which trees were sprayed with tap water.

\section{Carbohydrates in buds}

In the time within which no vital variations were noticed between 
any of the three dates of spray with mineral oil for carbohydrates in all sampled dates, mineral oil at 5\% was sig-nificantly increased total carbohydrates, total sugars and decreased non soluble carbohydrates when compared to the control (Table 6). With relevancy the impact of the date of spray treatments on total carbohydrates, it's clear from the current information that just about all treatments gave higher values of total carbohydrates and total sugars if compared to the control trees. The most effective results were obtained by spraying with mineral oil at the rate of $5 \%$ on the 15 th of January as compared to the untreated trees.

Table 4 Effect of mineral oil spray at different dates on fruit weight and fruit size of "Barkhar" apple fruit quality

\begin{tabular}{lllll}
\hline Date of spraying & \multicolumn{2}{c}{ Fruit weight (gm) } & \multicolumn{2}{c}{ Fruit size(cc3) } \\
& 2015 & 2016 & 2015 & 2016 \\
\hline Control & $51.27 \mathrm{c}$ & $50.10 \mathrm{c}$ & $63.54 \mathrm{c}$ & $61.32 \mathrm{c}$ \\
January, I & $59.13 \mathrm{a}$ & $59.12 \mathrm{a}$ & $75.78 \mathrm{~b}$ & $74.18 \mathrm{~b}$ \\
January, 15 & $59.49 \mathrm{a}$ & $59.21 \mathrm{a}$ & $79.09 \mathrm{a}$ & $80.10 \mathrm{a}$ \\
February, I & $55.06 \mathrm{~b}$ & $54.18 \mathrm{~b}$ & $71.72 \mathrm{~b}$ & $70.29 \mathrm{~b}$ \\
\hline
\end{tabular}

Mean pairs followed by different letters are significantly different $(p=0.05)$ by Duncan's test; $\mathrm{n}=6$

Table 5 Effect of mineral oil spray at different dates on fruit dimensions of "Barkhar" apple fruit quality

\begin{tabular}{lllll}
\hline $\begin{array}{l}\text { Date of } \\
\text { spraying }\end{array}$ & \multicolumn{2}{c}{ Fruit diameter $(\mathbf{c m})$} & \multicolumn{2}{c}{ Fruit height(cm) } \\
& $\mathbf{2 0 1 5}$ & $\mathbf{2 0 1 6}$ & $\mathbf{2 0 1 5}$ & $\mathbf{2 0 1 6}$ \\
\hline Control & $4.80 \mathrm{c}$ & $4.91 \mathrm{c}$ & $4.84 \mathrm{c}$ & $4.90 \mathrm{c}$ \\
January, I & $5.15 \mathrm{a}$ & $5.18 \mathrm{a}$ & $5.10 \mathrm{a}$ & $5.29 \mathrm{a}$ \\
January, I5 & $5.18 \mathrm{a}$ & $5.27 \mathrm{a}$ & $5.18 \mathrm{a}$ & $5.41 \mathrm{a}$ \\
February, I & $4.83 \mathrm{~b}$ & $4.90 \mathrm{~b}$ & $4.97 \mathrm{~b}$ & $5.00 \mathrm{~b}$
\end{tabular}

Mean pairs followed by different letters are significantly different $(p=0.05)$ by Duncan's test; $\mathrm{n}=6$

\section{Hormonal content in buds}

Foliar-applied mineral oil at $5 \%$ on 15 th of January increased the contents of total indols, indole- ${ }_{3}$-acetic acid (IAA) and gibberellic acid $\left(\mathrm{GA}_{3}\right)$ and decreased the contents of abscisic acid (ABA) within the floral buds of "Barkhar" apple trees when compared to the control in within which trees were sprayed with water as shown in Table 6 $\& 7$. The results of all hormones obtained with mineral oil sprayed at $5 \%$ on 15 th of January treatment were surpassed the results found with mineral oil sprayed at $5 \%$ on $1^{\text {st }}$ of January and $1^{\text {st }}$ of February in most of the sampled dates. The maximum contents of total indols, IAA and $\mathrm{GA}_{3}$ were obtained from buds applied with mineral oil on $15^{\text {th }}$ of January and collected in 15 February (buds were released from dormancy), while their minimum contents were obtained from buds applied with mineral oil at $5 \%$ on 1st of January and 1st of February and sampled in $15^{\text {th }}$ December $\& 1^{\text {st }}$ January (buds were still dormant) as shown in Table 5. For ABA, the alternative result was found. Additionally, the most ratios of IAA/ABA and $\mathrm{GA}_{3} / \mathrm{ABA}$ were noted within the $1^{\text {st }}$ February sample (buds were released from dormancy), whereas the minimum ones were found in the $15^{\text {th }}$ December and $1^{\text {st }}$ January samples (buds were still dormant) as shown in Table 7.
Table 6 Effect of mineral oil spray at different dates on water content, total carbohydrates, total sugars, non-soluble carbohydrates and total indoles in buds of "Barkhar" apple trees

\begin{tabular}{|c|c|c|c|c|c|}
\hline \multirow[t]{2}{*}{$\begin{array}{l}\text { Date of } \\
\text { spraying }\end{array}$} & \multicolumn{5}{|c|}{ Water content \% } \\
\hline & I5-Dec & I-Jan & I5-Jan & I-Feb & I5-Feb \\
\hline Control & $44.01 \mathrm{c}$ & $42.50 \mathrm{c}$ & $53.97 \mathrm{~b}$ & $58.35 a$ & $61.70 \mathrm{a}$ \\
\hline January, I & $44.01 \mathrm{c}$ & $42.50 \mathrm{c}$ & $53.98 b$ & $60.10 \mathrm{a}$ & $63.10 \mathrm{a}$ \\
\hline January, I5 & $44.01 \mathrm{lc}$ & $42.50 \mathrm{c}$ & $53.97 \mathrm{~b}$ & $61.25 \mathrm{a}$ & $64.12 \mathrm{a}$ \\
\hline \multirow[t]{2}{*}{ February, I } & $44.01 \mathrm{c}$ & $42.50 \mathrm{c}$ & $53.97 \mathrm{~b}$ & $58.35 \mathrm{a}$ & $62.99 \mathrm{a}$ \\
\hline & \multicolumn{5}{|c|}{ Total carbohydrates (mg g $\left.\mathrm{g}^{-1} \mathrm{DW}\right)$} \\
\hline Control & $112.86 \mathrm{c}$ & II3.66 & $115.38 \mathrm{a}$ & $115.40 \mathrm{a}$ & II $5.48 \mathrm{a}$ \\
\hline January, I & $112.86 \mathrm{c}$ & $\begin{array}{l}\text { II } 3.66 \\
b\end{array}$ & $117.38 \mathrm{a}$ & 118.94 a & $118.98 \mathrm{a}$ \\
\hline January, I5 & $112.86 \mathrm{c}$ & $\begin{array}{l}113.66 \\
b\end{array}$ & $117.38 \mathrm{a}$ & $119.00 \mathrm{a}$ & $119.20 \mathrm{a}$ \\
\hline \multirow[t]{2}{*}{ February, I } & $112.86 \mathrm{c}$ & $\begin{array}{l}\text { II3.66 } \\
b\end{array}$ & $117.38 \mathrm{a}$ & $118.76 \mathrm{c}$ & $119.48 \mathrm{a}$ \\
\hline & \multicolumn{5}{|c|}{ Total sugars (mg g $\left.g^{-1} \mathrm{DW}\right)$} \\
\hline Control & $77.66 \mathrm{~d}$ & $82.02 \mathrm{c}$ & $\begin{array}{l}100.10 \\
b\end{array}$ & $103.00 \mathrm{~b}$ & $106.73 \mathrm{a}$ \\
\hline January, I & $77.66 \mathrm{~d}$ & $82.02 \mathrm{c}$ & $\begin{array}{l}102.38 \\
b\end{array}$ & 107.99 b & $113.50 \mathrm{a}$ \\
\hline January, I5 & $77.66 \mathrm{~d}$ & $82.02 \mathrm{c}$ & $\begin{array}{l}100.10 \\
b\end{array}$ & $108.50 \mathrm{~b}$ & II $4.00 \mathrm{a}$ \\
\hline February, I & $77.66 \mathrm{~d}$ & $82.02 \mathrm{c}$ & $\begin{array}{l}100.10 \\
b\end{array}$ & $108.40 \mathrm{~b}$ & II $4.20 \mathrm{a}$ \\
\hline & \multicolumn{5}{|c|}{ Non-soluble carbohydrates (mg g-1 DW) } \\
\hline Control & $35.20 \mathrm{~d}$ & $31.64 d$ & $15.28 \mathrm{c}$ & $12.40 \mathrm{~b}$ & $8.75 \mathrm{a}$ \\
\hline January, I & $35.20 d$ & $31.64 d$ & $15.10 \mathrm{c}$ & $10.95 b$ & $5.48 \mathrm{a}$ \\
\hline January, I5 & $35.20 \mathrm{~d}$ & $31.64 \mathrm{~d}$ & $17.28 \mathrm{c}$ & $10.50 \mathrm{~b}$ & $5.20 \mathrm{a}$ \\
\hline \multirow[t]{2}{*}{ February, I } & $35.20 \mathrm{~d}$ & $31.64 d$ & $17.28 \mathrm{c}$ & $10.36 \mathrm{~b}$ & $5.28 \mathrm{a}$ \\
\hline & \multicolumn{5}{|c|}{ Total Indoles ( $\left.\mu g g^{-1} \mathrm{DW}\right)$} \\
\hline Control & $41.12 \mathrm{~d}$ & 44. $13 \mathrm{c}$ & $47.25 \mathrm{c}$ & 55. I5b & $60.33 a$ \\
\hline January, I & $41.12 \mathrm{~d}$ & 44. $13 \mathrm{c}$ & $47.25 \mathrm{~b}$ & $58.15 \mathrm{~b}$ & $68.77 a$ \\
\hline January, I5 & $41.12 \mathrm{~b}$ & 44. I3 c & $50.20 \mathrm{c}$ & $59.15 b$ & $69.01 \mathrm{a}$ \\
\hline February, I & $41.12 \mathrm{~b}$ & $44.13 \mathrm{c}$ & $47.25 \mathrm{c}$ & $55.15 b$ & $67.99 a$ \\
\hline
\end{tabular}

Mean pairs followed by different letters are significantly different $(p=0.05)$ by Duncan's test; $n=6$

\section{Total free amino acids in buds}

Data bestowed in Table 8 usually show that the total free amino acids content in "Barkhar" apple variety gradually increased from the first sample $15^{\text {th }}$ December till $1^{\text {st }}$ February (last sample) Concerning the effect of the date of spray treatments on total free amino acids, it's clear from this information that just about all dates gave higher values of total free amino acids in if compared to the untreated trees. The most effective results were obtained by spraying the trees by mineral oil at the rate of $5 \%$ on the $15^{\text {th }}$ of January. 
Table 7 Effect of mineral oil spray at different dates on hormonal content in buds of "Barkhar" apple trees

\begin{tabular}{|c|c|c|c|c|c|}
\hline \multirow[t]{2}{*}{$\begin{array}{l}\text { Date of } \\
\text { spraying }\end{array}$} & \multicolumn{5}{|c|}{ Indole acetic acid (IAA) ( $\mu g^{-1}$ DW) } \\
\hline & I5-Dec & I-Jan & I5-Jan & I-Feb & $\begin{array}{l}\text { I5- } \\
\text { Feb }\end{array}$ \\
\hline Control & $1.42 \mathrm{c}$ & $1.86 \mathrm{c}$ & $4.7 \mathrm{I} \mathrm{b}$ & $5.99 a$ & $6.11 \mathrm{a}$ \\
\hline January, I & $1.42 \mathrm{c}$ & $1.86 \mathrm{c}$ & 4.77 b & $6.14 a$ & $6.92 \mathrm{a}$ \\
\hline January, I5 & $\mathrm{I} .42 \mathrm{c}$ & $1.86 \mathrm{c}$ & $4.97 \mathrm{~b}$ & $6.81 \mathrm{a}$ & $6.93 \mathrm{a}$ \\
\hline \multirow[t]{2}{*}{ February, I } & $1.42 \mathrm{c}$ & $1.86 \mathrm{c}$ & $4.77 \mathrm{~b}$ & $6.20 \mathrm{a}$ & $6.89 \mathrm{a}$ \\
\hline & \multicolumn{5}{|c|}{ Gibberellic acid (GA3) ( $\left.\mu g g^{-1} D W\right)$} \\
\hline Control & $\mathrm{I} .4 \mathrm{I} \mathrm{c}$ & $\mathrm{I} .68 \mathrm{~b}$ & $1.85 b$ & $3.15 \mathrm{a}$ & $3.55 \mathrm{a}$ \\
\hline January, I & $\mathrm{I} .4 \mathrm{I} \mathrm{c}$ & $1.68 \mathrm{~b}$ & $\mathrm{I} .89 \mathrm{~b}$ & $3.49 \mathrm{a}$ & $3.95 \mathrm{a}$ \\
\hline January, I5 & $\mathrm{I} .4 \mathrm{I} \mathrm{c}$ & $\mathrm{I} .68 \mathrm{~b}$ & $1.95 \mathrm{~b}$ & $3.51 \mathrm{a}$ & $3.99 \mathrm{a}$ \\
\hline \multirow[t]{2}{*}{ February, I } & $\mathrm{I} .4 \mathrm{I} \mathrm{c}$ & $1.68 \mathrm{~b}$ & $\mathrm{I} .85 \mathrm{~b}$ & $3.15 \mathrm{a}$ & $3.98 \mathrm{a}$ \\
\hline & \multicolumn{5}{|c|}{ Abscisic acid (ABA) $\left(\mu g g^{-1} D W\right)$} \\
\hline Control & $4.20 \mathrm{~d}$ & $4.00 \mathrm{c}$ & $3.75 b$ & $2.80 \mathrm{~b}$ & $1.68 \mathrm{a}$ \\
\hline January, I & $4.20 \mathrm{~d}$ & $4.00 \mathrm{c}$ & $3.55 \mathrm{~b}$ & $2.28 \mathrm{~b}$ & $1.33 \mathrm{a}$ \\
\hline January, I5 & $4.20 \mathrm{~d}$ & $4.00 \mathrm{c}$ & $3.15 b$ & $2.25 \mathrm{~b}$ & $1.31 \mathrm{a}$ \\
\hline \multirow[t]{2}{*}{ February, I } & $4.20 d$ & $4.00 \mathrm{c}$ & $3.55 \mathrm{~b}$ & $2.30 \mathrm{~b}$ & $1.42 \mathrm{a}$ \\
\hline & \multicolumn{5}{|c|}{ IAA/ABA ratio } \\
\hline Control & $0.33 \mathrm{~d}$ & $0.42 \mathrm{~d}$ & $1.25 \mathrm{c}$ & $2.13 b$ & $3.63 \mathrm{a}$ \\
\hline January, I & $0.33 \mathrm{~d}$ & $0.42 \mathrm{~d}$ & I. $34 \mathrm{c}$ & $2.69 \mathrm{~b}$ & $5.20 \mathrm{a}$ \\
\hline January, I5 & $0.33 \mathrm{~d}$ & $0.42 \mathrm{~d}$ & $1.57 \mathrm{c}$ & $3.02 \mathrm{~b}$ & $5.29 \mathrm{a}$ \\
\hline \multirow[t]{2}{*}{ February, I } & $0.333 \mathrm{~d}$ & $0.42 \mathrm{~d}$ & $\mathrm{I} .34 \mathrm{c}$ & $2.69 \mathrm{~b}$ & $4.85 \mathrm{a}$ \\
\hline & \multicolumn{5}{|c|}{ GA3/ABA ratio } \\
\hline Control & $33.57 \mathrm{a}$ & $0.42 \mathrm{~d}$ & $0.49 \mathrm{~d}$ & $1.12 \mathrm{c}$ & $2.11 \mathrm{~b}$ \\
\hline January, I & $33.57 \mathrm{a}$ & $0.42 \mathrm{~d}$ & $0.53 \mathrm{~d}$ & $1.53 c$ & $3.01 \mathrm{~b}$ \\
\hline January, I5 & $33.57 \mathrm{a}$ & $0.42 \mathrm{~d}$ & $0.61 \mathrm{~d}$ & $1.56 \mathrm{c}$ & $3.04 b$ \\
\hline February, I & $33.57 \mathrm{a}$ & $0.42 \mathrm{~d}$ & $0.52 \mathrm{~d}$ & $1.12 \mathrm{c}$ & $2.80 \mathrm{~b}$ \\
\hline
\end{tabular}

Mean pairs followed by different letters are significantly different $(p=0.05)$ by Duncan's test; $\mathrm{n}=6$

\section{Phenolic content in buds}

Total soluble phenols and conjugated phenols will increase with foliar-applied mineral oil at 5\%, whereas the free phenols decreases within the floral buds of "Barkhar" apple trees in comparison to the control as shown in Table 8. The data of all phenols obtained with mineral oil at $5 \%$ treatment were surpassed the data found with the control in most of the sampled dates. The maximum contents of total soluble phenols and conjugated phenols were obtained from buds applied with mineral oil at $5 \%$ on the fifteenth of January and picked up in fifteen February (buds were discharged from dormancy), whereas their minimum contents were obtained from buds applied with mineral oil and sampled in 1st January (buds were still dormant).
For free phenols, the alternative result was found. Additionally, the utmost increase in total flavonoids were noted within the fifteen February sample (buds were discharged from dormancy), whereas the minimum ones were found within the first January samples (buds were still dormant) as shown in Table 8 .

Table 8 Effect of mineral oil spray at different dates on total free amino acids, total, free and conjugated phenols and total flavonoids content in buds of "Barkhar" apple trees

\begin{tabular}{|c|c|c|c|c|c|}
\hline \multirow{2}{*}{$\begin{array}{l}\text { Date of } \\
\text { spraying }\end{array}$} & \multicolumn{5}{|c|}{ Total free amino acids ( $\left.\mathrm{mg} \mathrm{g}^{-1} \mathrm{DW}\right)$} \\
\hline & I5-Dec & I-Jan & 15-Jan & I-Feb & I5-Feb \\
\hline Control & $51.95 \mathrm{c}$ & $58.03 \mathrm{c}$ & $74.12 b$ & $75.03 \mathrm{~b}$ & $77.01 \mathrm{a}$ \\
\hline January, I & $51.95 \mathrm{c}$ & $58.03 c$ & $82.03 \mathrm{~b}$ & $85.03 \mathrm{a}$ & $87.95 \mathrm{a}$ \\
\hline January, 15 & $51.95 \mathrm{c}$ & $58.03 \mathrm{c}$ & $74.12 \mathrm{~b}$ & $85.36 \mathrm{a}$ & $88.00 \mathrm{a}$ \\
\hline \multirow[t]{2}{*}{ February, I } & $51.95 \mathrm{c}$ & $58.03 \mathrm{c}$ & $74.12 \mathrm{~b}$ & $85.33 \mathrm{a}$ & $87.62 \mathrm{a}$ \\
\hline & \multicolumn{5}{|c|}{ Total phenols (mg g-1 DW) } \\
\hline Control & $36.29 c$ & $36.79 \mathrm{c}$ & $43.16 \mathrm{~b}$ & $50.4 \mathrm{I}$ a & $53.14 \mathrm{a}$ \\
\hline January, I & $36.29 c$ & $36.79 \mathrm{c}$ & $45.16 \mathrm{~b}$ & $52.01 \mathrm{a}$ & $56.22 \mathrm{a}$ \\
\hline January, I5 & $36.29 c$ & $36.79 \mathrm{c}$ & $43.16 \mathrm{~b}$ & $54.15 \mathrm{a}$ & $57.15 \mathrm{a}$ \\
\hline \multirow[t]{2}{*}{ February, I } & $36.29 c$ & $36.79 \mathrm{c}$ & $43.16 \mathrm{~b}$ & $50.4 \mathrm{I}$ a & $56.18 \mathrm{a}$ \\
\hline & \multicolumn{5}{|c|}{ Free phenols ( $\left.\mathrm{mg} \mathrm{g}^{-1} \mathrm{DW}\right)$} \\
\hline Control & $18.35 \mathrm{~d}$ & $13.91 \mathrm{c}$ & $12.48 \mathrm{~b}$ & $8.57 \mathrm{~b}$ & $7.61 \mathrm{a}$ \\
\hline January, I & $18.35 \mathrm{~d}$ & $13.91 \mathrm{c}$ & $10.15 \mathrm{~b}$ & $7.01 \mathrm{~b}$ & $6.41 \mathrm{a}$ \\
\hline January, 15 & $18.35 \mathrm{~d}$ & $13.91 \mathrm{c}$ & $12.48 \mathrm{~b}$ & $6.89 \mathrm{~b}$ & $6.35 \mathrm{a}$ \\
\hline \multirow[t]{2}{*}{ February, I } & $18.35 \mathrm{~d}$ & $13.91 \mathrm{c}$ & $12.48 \mathrm{~b}$ & $8.57 \mathrm{~b}$ & $6.37 \mathrm{a}$ \\
\hline & \multicolumn{5}{|c|}{ Conjugated phenols ( $\left.\mathrm{mg} \mathrm{g}^{-1} \mathrm{DW}\right)$} \\
\hline Control & $17.94 \mathrm{~d}$ & $22.88 \mathrm{~d}$ & $30.68 c$ & $4 \mathrm{I} .84 \mathrm{~b}$ & $45.53 \mathrm{a}$ \\
\hline January, I & $17.94 \mathrm{~d}$ & $22.88 \mathrm{~d}$ & $35.01 \mathrm{c}$ & $45.00 \mathrm{~b}$ & $49.81 \mathrm{a}$ \\
\hline January, 15 & $17.94 \mathrm{~d}$ & $22.88 \mathrm{~d}$ & $30.68 c$ & $47.26 \mathrm{~b}$ & $50.80 \mathrm{a}$ \\
\hline \multirow[t]{2}{*}{ February, I } & $17.94 \mathrm{~d}$ & $22.88 \mathrm{~d}$ & $30.68 c$ & $41.84 b$ & $49.8 I \mathrm{a}$ \\
\hline & \multicolumn{5}{|c|}{ Total flavonoids ( $\left.\mathrm{mg} \mathrm{g}^{-1} \mathrm{DW}\right)$} \\
\hline Control & $1.88 \mathrm{c}$ & $2.02 \mathrm{~b}$ & $2.15 \mathrm{~b}$ & $2.31 \mathrm{a}$ & $2.42 \mathrm{a}$ \\
\hline January, I & $1.88 \mathrm{c}$ & $2.02 \mathrm{~b}$ & $2.23 \mathrm{~b}$ & $2.45 \mathrm{a}$ & $2.55 \mathrm{a}$ \\
\hline January, 15 & $1.88 \mathrm{c}$ & $2.02 \mathrm{~b}$ & $2.15 \mathrm{~b}$ & $2.43 \mathrm{a}$ & $2.56 \mathrm{a}$ \\
\hline February, I & $1.88 \mathrm{c}$ & $2.02 \mathrm{~b}$ & $2.15 \mathrm{~b}$ & $2.31 \mathrm{a}$ & $2.53 \mathrm{a}$ \\
\hline
\end{tabular}

Mean pairs followed by different letters are significantly different $(p=0.05)$ by Duncan's test; $n=6$

\section{Chemical constituents of fruits}

Data of Table $9 \& 10$ clearly showed that spraying apple trees with the tested substance considerably improved the chemical constituents of fruits (total soluble solids (TSS), vitamin C and TSS/total acidity) as compared to the untreated trees. Such trend was true throughout the two studied seasons. The utmost increase were recorded with mineral 
oil at $5 \%$ on $15^{\text {th }}$ January which recorded $12.17 \& 12.15 \%$ within the first and second seasons, severally over the control trees for total soluble solids. The same trend was true for vitamin $\mathrm{C}$ and TSS/total acidity which recorded $3.82 \%$ with the primary season and \& $3.66 \%$ in the second season, respectively over the control trees for vitamin $\mathrm{C}$ and $23.86 \%$ in the first season and $23.36 \%$ in the second season, severally over the control trees for TSS/total acidity. On the opposite hand, the data in Table 9 additionally showed a marked decrease in total acidity concentrations in fruits once when trees were sprayed with the tested substance examination with the control trees.

\section{Discussion}

It is clear from the present study that breaking of dormancy is coincided with several changes in different chemical constituents of buds. Particularly the contents of water, carbohydrates (Table 6) endogenous hormones (Total natural indoles, IAA, GA and ABA) (Table 6) (Table 7) total free amino acids (Table 8) and endogenous phenols (Total, free, conjugated phenols and total flavonoids) (Table 8) play a vital role in regulating dormancy and bud break. In this concern, ${ }^{30}$ found that the transition of buds from the dormant stage to the bursting process is related to a rise within the water content within the tissue, mobilization of nutrients, activation of hydrolytic enzymes and intensification of respiration. The stimulating impact of mineral oil as foliar spray on total carbohydrates concentrations in buds of sprayed trees may be directly or indirectly thanks to sure enzymes that activate the anabolic processes resulting in the buildup of these substances. In this connection ${ }^{31}$ concluded that the period of increase in dry weight of both flower and vegetative buds appear to seem to result to the movement of metabolites may have come back from twigs, branches and roots of trees. Furthermore the rise in total free amino acids in buds after mineral oil treatments could also be because of the rise in mineral component movement specially nitrogen. In this concern ${ }^{32}$ found that there was a decrease in the nitrogen concentration of the woody tissues within the spring, significantly within the bark tissues of shoots. This was attributed to the movement of nitrogenous compounds from the bark and wood to the developing flower buds and growing points. Also ${ }^{33}$ indicated that the nitrogen (including amino acid) was low level in buds or roots throughout dormant stage and reached maximum just prior to bud break, the nitrogen stored mostly in the roots and translocate to buds before bud break and early growth. Moreover, ${ }^{34}$ observed that a probable correlation might exist between the state of dormancy and therefore the dominant total amino acids within the buds. Many studies centered on the link between the endogenous hormones and dormancy in buds. ${ }^{35}$ During the whole testing period, IAA and $\mathrm{GA}_{3}$ concentrations in buds of "Barkhar" apple at their release from dormancy was higher than those of before bud break. In contrast, ABA concentration in floral buds was higher before bud break than that of at dormancy releasing (Table 7). This suggested that higher IAA and $\mathrm{GA}_{3}$ contents and lower ABA content were needed for release of "Barkhar" apple buds from dormancy. In this concern ${ }^{35}$ showed that, growth-promoting hormones like $\mathrm{GA}_{3}$ and IAA found to be step by step exaggerated, whereas, growth-inhibiting hormones like ABA diminished throughout bud break. Moreover, the results showed that when the dormancy released, IAA/ABA ratio had the same changing tendency to IAA content (Table 4). Moreover, $\mathrm{GA}_{3} / \mathrm{ABA}$ ratio in buds had the same changing tendency to $\mathrm{GA}_{3}$ content during release from dormancy (Table 7). So, it could be presumed that $\mathrm{IAA} / \mathrm{ABA}$ and $\mathrm{GA}_{3} / \mathrm{ABA}$ ratio determined the metabolism direction. In addition, the ratios of IAA/ABA and $\mathrm{GA}_{3}$ ABA in apple buds were decreased in dormant buds, while increased in opening ones. In this concern, ${ }^{35}$ suggested that the balance of many hormones played a more important role than the amount of certain single hormone in the procedure of dormancy releasing and opining of buds. several High levels of endogenous IAA and $\mathrm{GA}_{3}$ and low level of endogenous ABA contents (Table 7) which noticed in "Barkhar" apple trees applied with mineral oil at different dates agreed with the explanation of, ${ }^{36}$ which assumption that mineral oil application magnified all substances stimulate flower formation, like $\mathrm{GA}_{3}$, Auxins etc., and shrivelled the flowering inhibitor like ABA etc. The physiological impact of oil on bud break is via respiration; thus its impact is powerfully influenced by the prevailing temperatures and during the week following application. It's been shown that a high day-time temperature is essential for an honest impact ${ }^{37}$ the cause for impact may be a temporary anaerobic condition within the buds. This resulting in alcohol production that successively causes the impact. ${ }^{38,39}$ Ethanol production explains the sensitivity of buds to treatments with oil throughout excessive temperature and once the soil is water logged. Beneath traditional things the phytotoxic risk is low, facultative application even at bud swell. It absolutely was shown that at this stage the swelling terminal buds square measure inhibitied (by oil) and this could increase the potential of the laterals to interrupt. ${ }^{40}$ In this concern, ${ }^{41}$ reported that in response to chemical element like oxygen deprivation, plants accumulate amino acid (Ala), succinate and c-amino saturated fatty acid (GABA). This development is presently explained by the activation of the GABA-shunt or the Ala fermentative pathway. ${ }^{42}$ The GABA-shunt could be a metabolic pathway that includes salt (Glut) within the TCA cycle, bypassing 2 enzymes of the cycle, specifically a-ketoglutarate dehydrogenase and Succinyl-CoA ligase. ${ }^{43}$ In this concern,${ }^{44}$ found that the oil-DNOC sprays definitely diode to terribly speedy shriveling of bud-scales. On the opposite hand chilling isn't An absolute demand for bud break, as a result of high temperatures, ${ }^{45}$ bud scale removal ${ }^{46}$ which means wounding stress, and anaerobic conditions ${ }^{38}$ will replace the chilling necessities olefine production will increase following numerous disturbances or stresses in plants. These disturbances is iatrogenic by abiotic or biological agents. ${ }^{47}$ Environmental stresses that induce ethene production embody physical wounding and cutting, chilling, drought, and water flooding. ${ }^{48}$ Moreover, stress, ensuing from several rest-breaking treatments like tree defoliation, shoots decapitation or application of boundchemicals is understood to extend ethene levels in plants ${ }^{49}$ during this respect, ${ }^{50}$ according that bud scale removal enhanced bud break and 1- aminocyclopropane-1-carboxylic acid (ACC) content in buds. Moreover, the mode of action of oil spray in increasing bud break ar to the reduction within the quantity of water lost from the buds and principally forestall them from drying out, so that, they will continue their traditional metabolic activities and mobilization of nutrients to the developed buds ${ }^{30,51}$ Environmental stresses that induce ethene production embody physical wounding and cutting, chilling, drought, and water flooding. ${ }^{48}$ Moreover, stress, ensuing from several rest-breaking treatments like tree defoliation, shoots decapitation or application of boundchemicals is understood to extend ethene levels in plants. ${ }^{49}$ During this respect, ${ }^{50}$ according that bud scale removal enhanced bud break and 1- aminocyclopropane-1carboxylic acid (ACC) content in buds. Moreover, the mode of action of oil spray in increasing bud break are to the reduction within the quantity of water lost from the buds and principally forestall them from drying out, so that, they will continue their traditional metabolic activities and mobilization of nutrients to the developed buds. ${ }^{30,51} \mathrm{In}$ general, dormancy-breaking agents and time of application absolutely affected advancing bud break still as flowering as a results of enhanced yield. Even supposing oil provides the same have an effect on bloom 
temporal arrangement, i might suspect that it works in an exceedingly completely different manner. i might guess that dormant oil will increase the physical phenomenon temperature of the tree, creating it "feels" hotter than actual close air temperature. So, if chill hours are accumulated, and also the nights are short enough, the tree would bloom since it's currently heat enough. ${ }^{52}$ The most of phenol compounds have been isolated from bud scales and have growth inhibitor role in buds. Literature reported by researchers and our works (Table 8) indicate that phenol compounds increased during rest in flower buds, then decreased after rest and completely eliminated at blooming. The chilling period influences during disappear them. Moreover ${ }^{53}$ reported that, phenol composition are redoubled from November to Gregorian calendar month and so, are shriveled in March and are eliminated on blooming stage in peach buds. Many studies have shown correlation between bud break and seasonal variation of phenols in trees. ${ }^{54}$ The analysis of dormant buds has shown that, phenol compounds seldom occur in an exceedingly free state among the cell; rather they're normally conjugated with different molecules. This finding may be taken some proof, that, phenols may be play vital role to protection buds throughout winter, dormant season and bud break. The decrease in free phenols and the increase in conjugated phenols after mineral oil at different date's treatment (Table 8) may be due to that the reduction in free phenols contrasted with the increase in total indoles (Table 6) i.e. endogenous promoters increased and consequently endogenous inhibitors decreased in the buds which led to increasing in plant growth parameters. Moreover, ${ }^{55}$ hypothesized that inhibitor flavonoids have protecting functions throughout several stresses and it appears that flavonoids accumulation within the leaves and flowers may be, helpful for its resistance to environmental stresses. The favorable effect of mineral oil at different dates on the date of flower bud opening (Table 1) may be due to their stimulation effect on natural $\mathrm{GA}_{3}$. In this connection, ${ }^{52}$ concluded that the induction of flowering may well be related to with a natural rise in GAs in plants to facilitate the formation of flowering endocrine within the leaves or expressing it within the growing buds. In our study, oil at totally different dates absolutely affected the date of bud gap. This may be due to the increase in $\mathrm{GA}_{3}$ and IAA and the decrease in ABA contents (Table 7). The increase in percentage of bud break and fruit set (Table 2) may be attributed to their stimulation effect of buds opening on formation of sink in shoot tip. In this concern ${ }^{56}$ reported that once a bud opens and attains the form of shoot, its tip acts as a powerful sink for metabolites and therefore being interception center for photosynthates and nutrient ends up in earlier begin of the bloom. The improving effect of mineral oil at different dates on yield and its components (Table 3) (Table 4) was mainly attributed to its positive action on enhancing growth parameters and photosynthetic pigments.

Moreover, the stimulating effect of mineral oil at different dates on physical characters (fruit weight, size and dimensions) and chemical fruit characters (T.S.S, total acidity, vitamin C) was mainly attributed to its positive action on enhancing growth parameters (Table 9) (Table10). Concerning the effect on TSS and acidity in fruits, the results showed that all treatments increased TSS significantly and decreased the total acidity. This increase in TSS may be due to the increase in synthesis of carbohydrates and its accumulation in the developing fruits of the treated trees. In this connection, ${ }^{57}$ mentioned that sugars diagrammatic regarding seventieth of the full soluble solids (T.S.S) in apple fruits and therefore the increase in sugars result in increase in TSS. He conjointly another that the rise in cellular sap result in decrease in acidity as a results of dilution of the organic acids furthermore ${ }^{58,59}$ on pear, found that the rise in TSS is also because of fast conversion of starch, and therefore the decrease in total acids content with advancement of ripening amount is also because of that the acids square measure regenerate into soluble solids during this connection ${ }^{60}$ urged that water and nutrients might also be mobilized to the growing points at the expense of the developing fruits. Moreover, ${ }^{58}$ found that the rise in accumulation of TSS and sugars throughout maturation has been associated with accumulation of aldohexose, plant product and better levels of ketohexose in "Bartlett" pear. Also, ${ }^{61}$ found that a daily decrease in acidity towards maturity can be because of consistent rise in temperature that ends up in varied degree of oxidization of substrates through respiration. Moreover, ${ }^{62}$ according that, the rise in antioxidant is also because of that fruits synthesize vitamin $\mathrm{C}$ from monosaccharide sugars, and thus the adequate offer of those precursors would greatly rely on the chemical action activity.

Table 9 Effect of mineral oil spray at different dates on T.S.S. and acidity of "Barkhar" apple fruit quality

\begin{tabular}{lllll}
\hline $\begin{array}{l}\text { Date of } \\
\text { spraying }\end{array}$ & T.S.S. (\%) & \multicolumn{3}{c}{ Acidity(\%) } \\
& 2015 & 2016 & 2015 & 2016 \\
\hline Control & $11.97 \mathrm{c}$ & $11.49 \mathrm{c}$ & $1.10 \mathrm{c}$ & $1.09 \mathrm{c}$ \\
January, I & $11.63 \mathrm{~b}$ & $11.70 \mathrm{~b}$ & $0.54 \mathrm{a}$ & $0.59 \mathrm{a}$ \\
January, 15 & $12.17 \mathrm{a}$ & $12.15 \mathrm{a}$ & $0.51 \mathrm{a}$ & $0.52 \mathrm{a}$ \\
February, I & $12.10 \mathrm{a}$ & $12.09 \mathrm{a}$ & $0.68 \mathrm{~b}$ & $0.66 \mathrm{~b}$ \\
\hline
\end{tabular}

Mean pairs followed by different letters are significantly different $(p=0.05)$ by Duncan's test; $\mathrm{n}=6$

Table 10 Effect of mineral oil spray at different dates on T.S.S./acid ratio and vitamin C of "Barkhar" apple fruit quality

\begin{tabular}{lllll}
\hline $\begin{array}{l}\text { Date of } \\
\text { spraying }\end{array}$ & \multicolumn{2}{l}{ T.S.S./acid ratio } & \multicolumn{2}{l}{$\begin{array}{l}\text { Vitamin C } \\
\text { juice })\end{array}$} \\
& 2015 & 2016 & 2015 & 2016 \\
\hline Control & $10.88 \mathrm{c}$ & $10.54 \mathrm{c}$ & $2.19 \mathrm{c}$ & $2.32 \mathrm{c}$ \\
January, I & $21.53 \mathrm{a}$ & $19.83 \mathrm{~b}$ & $2.47 \mathrm{~b}$ & $2.55 \mathrm{~b}$ \\
January, I5 & $23.86 \mathrm{a}$ & $23.36 \mathrm{a}$ & $3.82 \mathrm{a}$ & $3.66 \mathrm{a}$ \\
February, I & $17.79 \mathrm{~b}$ & $18.3 \mathrm{Ib}$ & $2.69 \mathrm{~b}$ & $2.85 \mathrm{~b}$ \\
\hline
\end{tabular}

Mean pairs followed by different letters are significantly different $(p=0.05)$ by Duncan's test; $\mathrm{n}=6$

\section{Conclusion}

The foliar application with mineral oil at different dates for "Barkhar" apple trees hastened the bud break, shortened the period of flowering and improved bud growth and fruit set. Mineral oil at 5\% on the $15^{\text {th }}$ January was found the foremost effective and considerably improved the contents of endogenous IAA, $\mathrm{GA}_{3}$, conjugated phenols and total flavonoids further as reduced ABA and free phenols content. This can be is led to the increasing within the percentages of the bud break and fruit set, further because the reduction within the period of flowering, and at last the increasing in the yield. Therefore, we tend to suggest mistreatment mineral oil at $5 \%$ as operator safer bud break promoters for the rise in "Barkhar" apple trees productivity. It should give a well strategy for the rise in the percentages of bud break and fruit set, and therefore the reduction in the flowering period to protect the floral buds against the high temperature in late winter in Egypt. 


\section{Acknowledgments}

None.

\section{Conflicts of interest}

The author declares there is no conflicts of interest.

\section{References}

1. Lang G, Early J, Martin G, et al. Endo-, para-, and ecodormancy: physiological terminology and classification for dormancy research. information systems division, National Agricultural Library. 1987;22:377.

2. Considine MJ, Considine JA. On the language and physiology of dormancy and quiescence in plants. $J$ Exp Bot. 2016;67(11):3189-3203.

3. Beauvieux R, Wenden B, Dirlewanger E. Bud dormancy in perennial fruit tree species: a pivotal role for oxidative cues. Front Plant Sci. 2018;9:657.

4. Sheard AG, Johnson SD, Cook NC. Effect of timing and concentration of rest breaking agents on budburst in 'Bing' sweet cherry under conditions of inadequate winter chilling in South Africa. S Afr J Plant Soil. 2009;26(2):73-79.

5. Seif El Yazal MA, Rady MM, Seif SA. Foliar-applied dormancy-breaking chemicals change the content of nitrogenous compounds in the buds of apple (Malus sylvestris Mill. cv. Anna) trees. Journal of Horticultural Science \& Biotechnology. 2012;87(4):299-304.

6. Hafez OM, Saleh MA, El Shamma MS, et al. Effect of thidiazuron and oil treatments on dormant break of Kanino apricot in warm climates. International Journal of Chem Tech Research. 2015;8(4):1423-1429.

7. Seif El Yazal MA, Rady MM, Seif El Yazal SA. Foliar-applied mineral oil enhanced hormones and phenols content and hastened breaking bud dormancy in "Astrachan" apple trees. International Journal for Empirical Education and Research. 2018;1:57-73.

8. Muhtaseb J, Ghnaim H. Budbreak, fruit quality and maturity of 'Superior' seedless grapesas affected by Dormex ${ }^{\circledR}$ under Jordan Valley conditions Fruits. 2008;63(3):171-178.

9. Eshghi S, Rahemi M, Karami A. Overcoming winter rest of grapevine grown in subtropical regions using dormancy-breaking agents. Iran Agricultural Research. 2010;29(1-2):99-106.

10. Jimenez VM, Guevara E, Herrera J, et al. Changes in hormone concentration during dormancy release of oil palm (Elaeis guineensis) seeds. Seed Sci and Technol. 2008;36(3):575-587.

11. Seif El Yazal MA, Seif El Yazal SA, Rady MM. Exogenous dormancybreaking substances positively change endogenous phytohormones and amino acids during dormancyrelease in 'Anna' apple trees. Plant Growth Regul. 2014;72(3):211-220.

12. Seif El Yazal MA, Seif El Yazal SA, Rady MM. Changes in promoter and inhibitor substances during dormancy release in apple buds under foliarapplied dormancy-breaking agents. International Journal for Empirical Education and Research. 2018;1:1-20.

13. Morsi M E, El Yazal MA. Effect of garlic and onion extract on bud break, growth, yield, berry quality and some chemical constituents of flam seedless and superior grapevines (Vitis vinifera L.). Egypt J Hort. 2008;35:1-28.

14. Zahra P, Majid R, Amin B. Seasonal changes of peroxidase, polyphenol oxidase enzyme activity and phenol content during and after rest in pistachio (Pistacia vera L.) flower buds. World Applied Sciences Journal. 2009;6(9):1193-1199.
15. Seif El Yazal MA, Rady MM, Seif El Yazal SA, et al. Changes in metabolic processes during break dormancy in apple buds under foliarapplied garlic extract. International Journal for Empirical Education and Research. 2018;1:36-58.

16. Parmentier CM, Rowland LJ, Line MJ. Water status in relation to maintenance and release from dormancy in blueberry flower buds. $J$ Am Soc Hort Sci. 1998;123(5):762-769.

17. Faust M, Liu D, Millard MM, et al. Bound versus free water in dorman apple buds a theory for endodormancy. Hort Science. 1991;26(7):887890.

18. Gemma H. Dormancy breaking in Japanese pears grown in a heated greenhouse. Acta Hort. 1995;395:57-67.

19. Judd MJ, Meyer DH, Meekings JS, et al. An FTIR study of the induction and release of kiwifruit buds from dormancy. J Sci Food Agric. 2010;90(6):1071-1080.

20. Shindy WW, Smith OE. Identification of plant hormones from cotton ovules. Plant Physiol. 1975;55(3):550-554.

21. Hashem HA. Molecular and physiological studies on heat shock protein expression in a stressed plant. Department of botany, Faculty of Science, Ain Shams University, Cairo, Egypt. 2000.

22. Snellings SL, Takenaka NE, Kim Hayes Y, et al. Rapid colorimetric method to detect indole in shrimp with gas chromatography mass spectrometry confirmation. Journal of Food Science. 2003;68(4):15481553.

23. Galicia L, Nurit E, Rosales A, et al. Laboratory protocols: maize nutrition quality and plant tissue analysis laboratory. Mexioc DF: CIMMYT. 2008.

24. Zhishen J, Mengcheng T, Jianming W. The determination of flavonoid contents in mulberry and their scavenging effects on superoxide radicals. Food Chem. 1999;64(4):555-559.

25. Rao P, Pattabiraman TN. Reevaluation of the phenolsulfuric acid reaction for the estimation of hexoses and pentoses. Anal Biochem. 1989;181(1):18-22.

26. AOAC. Official methods of analysis of the association of official agricultural chemists. $16^{\text {th }}$ ed. Washington DC, USA. 1995.

27. Jayarman J. Laboratory Manual in Biochemistry. Wiley Eastern Limited New York. 1981;61-73.

28. Chen L, Chen Q, Zhang Z, et al. Anovel colorimetric determination of free amino acids content in tea infusions with 2,4-dinitrofluorobenzene. Journal of Food Composition and Analysis. 2009;22(2):137-141.

29. Gomez KA, Gomez AA. Statistical Analysis Procedure of Agricultural Research. John Wiley and Sons, New York. 1984;25-30.

30. Borkowska B. Releasing the single apple buds from dormancy under the influence of low temperature, BA and ABA. Fruit Sci Rep. 1980;7:174183.

31. Bachelard EP, Wightman F. Biochemical and physiological studies on dormancy release in tree buds. Can J Bot. 1973;51(12):2315-2326.

32. Hill Cottingham DG. The effect of climate and time of application of fertilizer on the development and crop performance of fruit trees. In recent aspects of nitrogen metabolism in plants. In: EJ Hewitt, CV Cutting, editors. Acdemic Press, London and New York: 1968. p. 234 253.

33. Kuroi I. Studies on the growth promotion of grape vines by the lime nitrogen treatment during the rest period. Memoirs Fac Agric. Niigata Univ. 1974;12:1-17. 
34. Tromp J. Storage and mobilization of nitrogenous compounds in apple trees with special reference to arginine. 1969.

35. Dong Qin, Jin Zheng Wang, Jian min Guo, et al. The Relation between endogenous hormones and late-germination in buds of "Avrolles" apple. Agric Sci China. 2009;8(5):564-571.

36. Seif El Yazal MAS. Physiological studies on rest period of apple trees Cairo University. 1990.

37. Erez A. The effect of temperature on the activity of oil + dinitro-o-creso sprays to break the rest of apple buds. Hort Science. 1979;14: 141-142.

38. Erez A, Couvillon GA, Kays SJ. The effect of oxygen concentration on the release of peach leaf buds from rest. Hort Science. 1980;15:39-41.

39. Erez A. Means to compensate for insufficient chilling to improve bloom and leafing. Acta Hort. 1995;395:81-95.

40. Erez A, Zur A. Breaking the rest of apple buds by narrow-destillationrange oil and dinitro-o-cresol. Scientia Horticulturae. 1981;14(1):47-54

41. Miyashita Y, Good AG. Contribution of the GABA-shunt to hypoxia induced alanine accumulation in roots of Arabidopsis thaliana. Plant Cell Physiol. 2008;49(1):92-102.

42. Rocha M, Licausi M, Araujo WL, et al. Glycolysis and the tricarboxylic acid cycle are linked by alanine minotransferase during hypoxia induced by water logging of Lotus japonicas. Plant Physiol. 2010;152(3):15011513.

43. Sweetlove LJ, Beard KFM, Nunes Nessi A, et al. Not just a circle: flux modes in the plant TCA cycle. Trends Plant Sci. 2010;15(8):462-470.

44. Elsenfaz SA. Effect of DNOC on ABA concentration, fruitles diameter cell area and number of apples flower buds. Acta Horticultural. 1990;279:437-445.

45. Tohbe M, Mochioka R, Horiuchi S, et al. Role of ACC and glutathione during breaking of dormancy in grapevine buds by high temperature treatment. J Japan Soc Hort Sci. 1998;67:897-901.

46. Mizutani F, Hino A, Amano S, et al. Effect of calcium cyanamide, GA3 and scale removal on bud break, ethylene production and ACC content in grapevine buds. Mem Coll Agr Ehime Univ. 1995;40:91-97.

47. Abeles FB, Morgan PW, Saltveit ME. Ethylene in Plant Biology. Academic Press, San Diego. 1992.

48. Yang SF, Oetiker JH. Molecular biology of ethylene biosynthesis and its application in horticulture. J Japan Soc Hort Sci. 1998;67(6): 12091214.
49. Abeles. Ethylene in plant biology. Academic Press. New York. 1973.

50. El Shereif AR, Mizutani F, Onguso JM, et al. Effect of bud scale removal and AOA on bud break and ACC content of 'Muscat Bailey A' grapevines. Journal of Applied Horticulture. 2006;8(2):125-128.

51. Deviller GDB. Effect of oil spray on Bartlett pear. So Afric Dep Agric Sci Bull. 1957;250.

52. Subha drabandhu S. Induction of bud break in apple trees that received insufficient chilling by hydrogen cyanamide. Acta Hort. 1995;409:171178.

53. Codignola A, Maffel M, Fieschi M. Phenols and bud dormancy, qualitative variation in endogenous phenols in dormant buds of Fagus sylvatica L. New Phytol. 1988;108:473-477.

54. Codignola A, Maffel M, Fieschi M. Phenols and bud dormancy. New Phytol. 1988;110:473-477.

55. Shao L, Shu, Z, Sun SH, et al. Antioxidation of anthocyanins in photosynthesis under high temperature stress. J Integr Plant Biol. 2007;49(9):1341-1351.

56. Skene KG. Acomparison of the effects of cycocell and tipping on fruit set Vitis vinefra L. Aust J Bio Sci. 1969;22(6):1305-1312.

57. Boghdadi HA. Principles of fruit production. Dar El-Maerif, Cairo, Egypt, 3rd edtion.1964;663-667.

58. Dame CD, Lonard SJ, Luh BS, et al. The influence of ripeness on the organic acids, sugars and pectin of canned Bartlett pears. Fd Techn Champing. 1956;10:23-33.

59. Mann SS, Singh B. Some aspects on development physiology of patharankh pear. Acta Hort. 1990;279:155-158.

60. George AP, Nissen RJ, Lioyed J, et al. Factors affecting fruit quality of low chill stone fruit in subtropical Australia. Acta Hort. 1990;279:559564.

61. Nitsch JP. The physiology of fruit growth. Ann Rev Plant Physiol. 1953;4:199-236.

62. Mapson LW. Vitamin in fruits. In: AC Hulme, Editor. The Biochemistry of fruits and their production. Academic press. New York. 1970. 